Vol. 11 (2002): 301-310.

\title{
Nutritional status in commercial currant fields
}

\author{
Raina Niskanen \\ Department of Applied Biology, Horticulture, PO Box 27, FIN-00014 University of Helsinki, Finland, \\ e-mail: raina.niskanen@helsinki.fi
}

\begin{abstract}
The nutritional status on commercial currant fields was elucidated by advisory analytical data of 357 pairs of soil and leaf samples from commercial black, red and white currant fields in Southern and Middle Finland. The purpose was to investigate how nutrient concentrations in soil and leaves fitted in the recommended ranges, correlated with each other and to evaluate their usefulness in diagnosis of nutritional status. Soil $\mathrm{pH}\left(\mathrm{H}_{2} \mathrm{O}\right)$ and extractable nutrients $\left(\mathrm{NO}_{3}-\mathrm{N}, \mathrm{P}, \mathrm{K}, \mathrm{Ca}, \mathrm{Mg}, \mathrm{B}, \mathrm{Cu}, \mathrm{Mn}\right)$ and leaf nutrients ( $\mathrm{N}, \mathrm{P}, \mathrm{K}, \mathrm{Ca}, \mathrm{Mg}, \mathrm{B})$ were analysed. The mean soil $\mathrm{pH}, \mathrm{P}, \mathrm{K}$ and $\mathrm{Mn}$ were in the recommended ranges. Over $50 \%$ of soil $\mathrm{P}$ and $60 \%$ of $\mathrm{Mg}$ results and the greatest part of Ca results passed below the lower recommended limits, but soil $\mathrm{B}$ and $\mathrm{Cu}$ were frequently over the upper recommended limits. The mean leaf $\mathrm{N}, \mathrm{P}$ and $\mathrm{K}$ on all currants, $\mathrm{Mg}$ on black and red currants and $\mathrm{Ca}$ and $\mathrm{B}$ on black currant were within the recommended limits. The lower recommended limit of $\mathrm{Mg}$ was passed below in $74 \%$ of white currant leaf samples. Positive correlations were found between soil and leaf nutrient concentrations for $\mathrm{P}, \mathrm{Ca}$ and $\mathrm{Mg}$. The recommended lower soil analysis limits might possibly be too high for coarse soils, because low values of soil $\mathrm{P}, \mathrm{Mg}$ and $\mathrm{Ca}$ were common. The nutrients also might not be evenly distributed in the sampled soil layer but might be accumulated in a thin surface soil layer because of repeated surface broadcasting of fertilizers.
\end{abstract}

Key words: black currants, leaf analysis, macro- and micronutrients, red currants, Ribes nigrum, Ribes $x$ pallidum, soil $\mathrm{pH}$, soil testing, white currants

\section{Introduction}

The chemical composition of a plant changes with nutrient supply, although the change is by no means commensurate with the variation in external supplies (Asher and Loneragan 1967, Spear et al. 1978). Soil analysis alone is not al- ways a satisfactory guide to the fertilization of perennial plants like berry and fruit crops (Bould et al. 1960). Recommendations based on soil analysis assume that there is a direct relationship between the extractable nutrients in the soil and the uptake by plants. However, this relationship is affected by environmental factors like soil moisture. Therefore leaf analysis can be a more 


\section{Niskanen, R. Nutritional status in currant fields}

reliable tool in assessing the nutritional status and response to fertilizers and in giving information about the real uptake of nutrients. In Finland, leaf analysis has been used in the fertilization recommendations for currants since the 1970s. However, the values recommended for leaf nutrients have largely been based on the research done abroad. In addition, the studies have mainly concentrated on black currant (Ljones 1963, Bould 1964, 1969, Bjurman 1971, Bould and Parfitt 1972, Vang-Petersen 1973, Säkö and Laurinen 1979, Aaltonen and Dalman 1993, Niskanen et al. 1993, 1999, Kongsrud and Nes 1999, Aflatuni et al. 2001), and there are few studies on red and white currants (Vang-Petersen 1973, Ljones 1984, Aaltonen 1990, 1992, Aaltonen and Dalman 1993, Niskanen et al. 1993, 1994, 1999, Dierend et al. 1998, Rupp and Tränkle 2000). Therefore, recommendations for black currant (Ribes nigrum L.) have largely been applied also to red and white currants (Ribes x pallidum Otto \& Dietr.).

Fluctuations in berry yields are major problems in commercial currant production (Voipio and Niskanen 1990, Niskanen and Matala 1991), and more knowledge is needed for solving the causes of low yields. More research is needed on the effects of fertilization on the berry yield and the applicability of soil and leaf analysis in the advisory work on fertilization (Niskanen 1989). Both environmental and economical viewpoints assume that fertilization must be as appropriate as possible. In practical cultivation, there have been problems in the interpretation and combination of soil and leaf analysis results, because they give sometimes contrary comprehensions of the nutritional status. When nutrient concentrations in leaves are within the recommended range, it has been difficult to use them as a basis for optimization of fertilization, because the values vary depending on the conditions. Because of these problems, leaf analysis has not been useful enough and has not met the needs of practical cultivation (Matala 1999). Therefore, the use of commercial analysis of leaf samples has decreased radically (Alainen 1999, personal communication).
The intention of this study was to elucidate the nutritional status on Finnish commercial currant fields, to compare leaf nutrient levels of different currant species, and to investigate how nutrient concentrations in soil and leaves fitted in the recommended ranges, correlated with each other and to evaluate their usefulness in diagnosis of nutritional status.

\section{Material and methods}

To study the nutritional status of commercial currant fields, soil testing and leaf macronutrient data provided by Soil Testing Service Ltd was investigated. During 1982-1991, soil and leaf samples were taken by growers after harvest at the end of August or at the beginning of September in commercial black, red and white currant fields located in Southern and Middle Finland. The total numbers of soil and leaf samples were 287, 51 and 19 for black, red and white currant fields, respectively. The samples were sent to Soil Testing Service Ltd for analysis. The cultivars were not always reported by the growers. However, 'Red Dutch', 'Rondom' and 'White Dutch' grew in some red and white currant fields, and the main black currant cultivar was 'Öjebyn'.

According to the instructions (Soil Testing Service Ltd), soil samples should consist of 810 subsamples taken from the depth of about 0 $20 \mathrm{~cm}$ and mixed thoroughly. The textural and humus content classes of soils were estimated by finger assessment. The $\mathrm{pH}$ and nitrate nitrogen were determined in soil-water suspension (1:2.5) after 12 hours standing. An ion-specific electrode was used for the measurement of the nitrate nitrogen. Before 1989 , only nitrate nitrogen values higher than $10 \mathrm{mg} \mathrm{l}^{-1}$ soil were reported. Soil $\mathrm{P}, \mathrm{K}, \mathrm{Ca}$ and $\mathrm{Mg}$ were extracted by acid ammonium acetate $(0.5 \mathrm{M}$ acetic acid, $0.5 \mathrm{M}$ ammonium acetate, $\mathrm{pH} 4.65$, ratio $1: 10 \mathrm{v} / \mathrm{v}, 1 \mathrm{~h}$ ) (Vuorinen and Mäkitie 1955). Soil boron was extracted by hot water (Berger and Truog 1944) 
Vol. 11 (2002): 301-310.

and copper and manganese by acid ammonium acetate-EDTA solution (Lakanen and Erviö 1971). Phosphorus was determined by a modification (Vuorinen and Mäkitie 1955) of molybdenum blue method, potassium and calcium by flame photometry, magnesium, copper and manganese by atomic absorption spectrophotometry and boron by plasma emission spectroscopy. The extraction method for soil copper and manganese was changed in 1986 and, differing from the other elements, only the results of the period 1986-1991 were included in the present study for these two nutrients. The results of manganese are given as $\mathrm{pH}$-corrected values. The measured manganese concentrations ( $\mathrm{mg} \mathrm{l}^{-1}$ of soil) were multiplied by a coefficient which is dependent on soil pH (Sillanpää 1982).

The leaf samples consisted of 40-100 completely developed healthy leaf blades (about $100 \mathrm{~g}$ of fresh weight) of new shoots from all around the bushes. Air-dried leaf samples were ground and ashed at $550^{\circ} \mathrm{C}$ and the ash was dis- solved in $2 \mathrm{M} \mathrm{HCl}$. P, K, Ca, Mg and B in ash extracts were determined by plasma emission spectroscopy. Leaf $\mathrm{N}$ was determined by the Kjeldahl method.

\section{Results}

The samples collected from commercial currant fields during 1982-1991 consisted mainly of coarse mineral soils (Table 1). The greatest group consisted of sandy moraines of medium humus content. The mean soil $\mathrm{pH}$ was in the recommended range, but the values were under the lower limit in part of the soil samples (Table 2). The percentage of low $\mathrm{pH}$ values was highest for red currant fields. Nitrate $\mathrm{N}$ was below the range recommended for samples collected in autumn. The data on nitrate $\mathrm{N}$ was limited and included only samples from black currant fields where the

Table 1. Percentage of soil samples from currant fields of different textural and humus content classes during $1982-1991$.

\begin{tabular}{|c|c|c|c|c|c|}
\hline & & & \multicolumn{3}{|c|}{$\%$ of currant fields } \\
\hline & & & $\begin{array}{c}\text { Black } \\
(\mathrm{n}=287)\end{array}$ & $\begin{array}{c}\text { Red } \\
(n=51)\end{array}$ & $\begin{array}{c}\text { White } \\
(\mathrm{n}=19)\end{array}$ \\
\hline \multirow[t]{4}{*}{ Textural class $^{1}$} & Clay, silt, loam & & 12 & 0 & 0 \\
\hline & Fine sand & & 21 & 10 & 21 \\
\hline & Sandy moraine & & 60 & 73 & 79 \\
\hline & No information & & 5 & 18 & 0 \\
\hline \multirow[t]{6}{*}{ Humus content $^{2}$} & Low & & 6 & 4 & 16 \\
\hline & Medium & & 64 & 57 & 79 \\
\hline & Rich & & 21 & 22 & 5 \\
\hline & Very rich & & 1 & 0 & 0 \\
\hline & Mull & & 2 & 0 & 0 \\
\hline & No information & & 5 & 18 & 0 \\
\hline \multicolumn{6}{|c|}{${ }^{1}$ Percentage of particle size fractions in textural classes: } \\
\hline Diameter, mm & Clay & Silt & Loam & Coarser soils & \\
\hline$<2$ & $\geq 30$ & $<30$ & $<30$ & $<30$ & \\
\hline $2-20$ & & $>50$ & $<50$ & $<50$ & \\
\hline$>20$ & & & $<50$ & $>50$ & \\
\hline
\end{tabular}




\section{Niskanen, $R$. Nutritional status in currant fields}

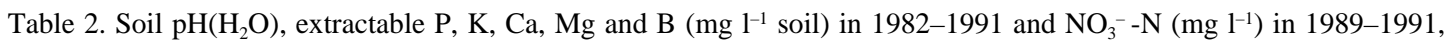
copper ( $\left.\mathrm{mg} \mathrm{l}^{-1}\right)$ and $\mathrm{pH}$-corrected manganese in 1986-1991 and percentage of samples with values below (low values) and above (high values) the ranges recommended for currant fields.

\begin{tabular}{|c|c|c|c|c|c|c|c|}
\hline \multirow[t]{2}{*}{ Property $^{1}$} & \multirow[t]{2}{*}{ Currant } & \multirow[t]{2}{*}{$\mathrm{n}$} & \multirow[t]{2}{*}{ Mean } & \multirow[t]{2}{*}{$\mathrm{SD}$} & \multirow[t]{2}{*}{ Range } & \multicolumn{2}{|c|}{ Percentage of } \\
\hline & & & & & & low values & high values \\
\hline \multirow[t]{3}{*}{$\mathrm{pH}$} & Black & 287 & 6.3 & 0.4 & $5.3-7.4$ & 27 & 14 \\
\hline & Red & 51 & 6.2 & 0.4 & $5.2-7.0$ & 39 & 14 \\
\hline & White & 19 & 6.4 & 0.5 & $5.7-7.2$ & 21 & 37 \\
\hline \multirow[t]{3}{*}{$\mathrm{P}$} & Black & 287 & 22 & 17 & $1-106$ & 59 & 14 \\
\hline & Red & 51 & 26 & 21 & $4-95$ & 51 & 22 \\
\hline & White & 19 & 20 & 10 & $8-43$ & 53 & 5 \\
\hline \multirow[t]{3}{*}{ K } & Black & 287 & 187 & 80 & $20-562$ & 32 & 6 \\
\hline & Red & 51 & 195 & 92 & $40-380$ & 35 & 8 \\
\hline & White & 19 & 164 & 80 & $55-320$ & 53 & 0 \\
\hline \multirow[t]{3}{*}{$\mathrm{Mg}$} & Black & 287 & 198 & 88 & $40-690$ & 61 & 4 \\
\hline & Red & 51 & 168 & 65 & $50-395$ & 78 & 0 \\
\hline & White & 19 & 164 & 57 & $80-255$ & 63 & 0 \\
\hline \multirow[t]{3}{*}{$\mathrm{Ca}$} & Black & 287 & 1466 & 461 & $500-4100$ & 91 & 3 \\
\hline & Red & 51 & 1430 & 451 & $625-2525$ & 86 & 0 \\
\hline & White & 19 & 2005 & 1577 & $725-8000$ & 74 & 16 \\
\hline \multirow[t]{3}{*}{ B } & Black & 287 & 1.0 & 0.4 & $0.3-2.5$ & 8 & 48 \\
\hline & Red & 51 & 1.2 & 0.5 & $0.6-2.6$ & 0 & 63 \\
\hline & White & 19 & 1.6 & 0.6 & $0.6-2.8$ & 0 & 90 \\
\hline \multirow[t]{3}{*}{$\mathrm{Cu}$} & Black & 159 & 10.5 & 7.9 & $1.1-50.8$ & 8 & 75 \\
\hline & Red & 30 & 6.6 & 4.0 & $2.0-6.0$ & 0 & 53 \\
\hline & White & 17 & 11.7 & 6.4 & $1.8-25.6$ & 6 & 88 \\
\hline \multirow[t]{3}{*}{$\mathrm{Mn}$} & Black & 159 & 37 & 24 & $6-165$ & 38 & 8 \\
\hline & Red & 30 & 37 & 17 & $11-96$ & 23 & 3 \\
\hline & White & 17 & 55 & 72 & $20-330$ & 18 & 12 \\
\hline $\mathrm{NO}_{3}{ }^{-}-\mathrm{N}$ & Black & 33 & 7.5 & 6.5 & $1.2-31.0$ & & \\
\hline
\end{tabular}

1 Ranges recommended for coarse mineral soils (Viljavuuspalvelu 1997): pH 6.1-6.5, P 20-40, K 150-350, Ca 20002600, Mg 200-400, B 0.6-0.9, Cu 2.7-5.0, $\mathrm{NO}_{3}^{-}{ }^{-} \mathrm{N} 30-50 \mathrm{mg} \mathrm{l}^{-1}$ soil, Mn-value 25-75

$\mathrm{SD}=$ standard deviation, $\mathrm{n}=$ number of samples

nitrate $\mathrm{N}$ concentration was $\leq 10 \mathrm{mg} \mathrm{l}^{-1}$ soil in $83 \%$ of samples. The means of soil $\mathrm{P}$ and $\mathrm{K}$ were in the recommended ranges. However, $\mathrm{P}, \mathrm{Mg}$ and Ca values commonly fell below the recommended lower limits. Soil B and $\mathrm{Cu}$ were frequently over the upper recommendation limit. On the average, soil manganese was in the recommendation range. Low manganese values were most common on black currant fields.

The mean values of $\mathrm{N}, \mathrm{P}$ and $\mathrm{K}$ in currant leaves were in the recommended ranges (Table 3). In black and white currant leaves, K level was good but $\mathrm{N}$ was below the recommended lower limit in one-fifth of the samples. High P values were most common in red currant leaves and high $\mathrm{K}$ values in black currant leaves. The mean $\mathrm{Mg}$ concentration in leaves of black and red currants were within the recommended range, low values being most common in white currant leaves. On average, $\mathrm{Ca}$ and $\mathrm{B}$ in black currant 
Vol. 11 (2002): 301-310.

Table 3. N, P, K, Mg, Ca ( $\mathrm{g} \mathrm{kg}^{-1}$ of dry matter) and B (mg kg-1 of dry matter) in currant leaves 1982-1991 and percentage of samples with nutrient values below (low values) and over (high values) the recommendation range.

\begin{tabular}{|c|c|c|c|c|c|c|c|}
\hline \multirow[t]{2}{*}{ Nutrient $^{1}$} & \multirow[t]{2}{*}{ Currant } & \multirow[t]{2}{*}{$\mathrm{n}$} & \multirow[t]{2}{*}{ Mean } & \multirow[t]{2}{*}{ SD } & \multirow[t]{2}{*}{ Range } & \multicolumn{2}{|c|}{ Percentage of } \\
\hline & & & & & & low values & high values \\
\hline \multirow[t]{3}{*}{$\mathrm{N}$} & Black & 287 & 24.1 & 5.2 & $10.2-54.5$ & 18 & 8 \\
\hline & Red & 51 & 26.9 & 5.2 & $16.5-45.7$ & 6 & 6 \\
\hline & White & 19 & 24.9 & 4.5 & $16.9-31.2$ & 21 & 0 \\
\hline \multirow[t]{3}{*}{$\mathrm{P}$} & Black & 287 & 5.6 & 1.7 & $2.2-10.1$ & 5 & 9 \\
\hline & Red & 51 & 6.5 & 3.7 & $2.2-15.7$ & 12 & 26 \\
\hline & White & 19 & 5.1 & 1.4 & $3.1-8.1$ & 0 & 5 \\
\hline \multirow[t]{3}{*}{$\mathrm{K}$} & Black & 287 & 17.2 & 4.5 & $8.7-34.6$ & 1 & 26 \\
\hline & Red & 51 & 30.6 & 7.3 & $17.1-47.9$ & 8 & 12 \\
\hline & White & 19 & 31.7 & 3.2 & $25.8-35.9$ & 0 & 0 \\
\hline \multirow[t]{3}{*}{$\mathrm{Mg}$} & Black & 287 & 5.1 & 1.3 & $2.3-9.3$ & 17 & 3 \\
\hline & Red & 51 & 3.4 & 0.8 & $1.7-4.9$ & 28 & 0 \\
\hline & White & 19 & 2.8 & 0.7 & $1.7-4.0$ & 74 & 0 \\
\hline \multirow[t]{2}{*}{$\mathrm{Ca}$} & Black & 19 & 20.7 & 3.5 & $12.0-25.6$ & & \\
\hline & Red & 6 & 31.0 & 2.6 & $27.8-35.6$ & & \\
\hline \multirow[t]{2}{*}{ B } & Black & 40 & 34.3 & 10.2 & $19.5-82.0$ & & \\
\hline & Red & 6 & 37.2 & 2.3 & $35.3-41.0$ & & \\
\hline
\end{tabular}

${ }^{1}$ Recommendation ranges for nutrients in August (Viljavuuspalvelu 1997):

\begin{tabular}{lllllll} 
& $\mathrm{N}$ & $\mathrm{P}$ & $\mathrm{K}$ & $\mathrm{Mg}$ & $\mathrm{Ca}$ & $\mathrm{B}$ \\
Currant & \multicolumn{2}{c}{$\mathrm{g} \mathrm{kg}^{-1}$ of dry matter } & & & $\mathrm{mg} \mathrm{kg}^{-1}$ of dry matter \\
Black & $20-30$ & $3-8$ & $10-20$ & $4-8$ & $20-30$ & $20-60$ \\
Red, white & $20-35$ & $3-8$ & $20-40$ & $3-5$ & $10-25$ & $20-60$
\end{tabular}

$\mathrm{SD}=$ standard deviation, $\mathrm{n}=$ number of samples

leaves were in the recommended range, although the number of analyses was low. The most remarkable distinction between nutrient levels in leaves of different currant species was a higher $\mathrm{K}$ level for red and white currants as compared with black currant. Mg was the only nutrient with higher values for black currant than for red and white currants. The other nutrient levels were higher for red currant than for black currant.

Positive correlations between leaf and soil nutrients were rather weak for $\mathrm{P}$ in black and red currant fields (Fig. 1). Values of correlation coefficients were rather low also for $\mathrm{Mg}$ of black currant and red currant (Fig. 2). A weak negative correlation was found between soil and leaf $\mathrm{K}$ in red currant fields (Fig. 3).

\section{Discussion}

The ranges recommended (Viljavuuspalvelu 1997) in Finland for macronutrient concentrations in currant leaves are wider and for nearly all nutrients higher than the optimum ranges for black currant leaves suggested in England (N 2930, P 2.5-3.0, K 10-15, Mg 1.0-1.5 g kg-1 dry matter) (Bould 1964, 1969) and values recommended for all currants in Norway and Sweden (N 26-29, P 1.5-2.0, K 12-16, Ca 14-17 and $\mathrm{Mg}$ 2.5-3.5 $\mathrm{g} \mathrm{kg}^{-1}$ dry matter) (Larsson and Svensson 1989).

In commercial currant fields, nutrient values below the recommended lower limits were more 
Niskanen, $R$. Nutritional status in currant fields
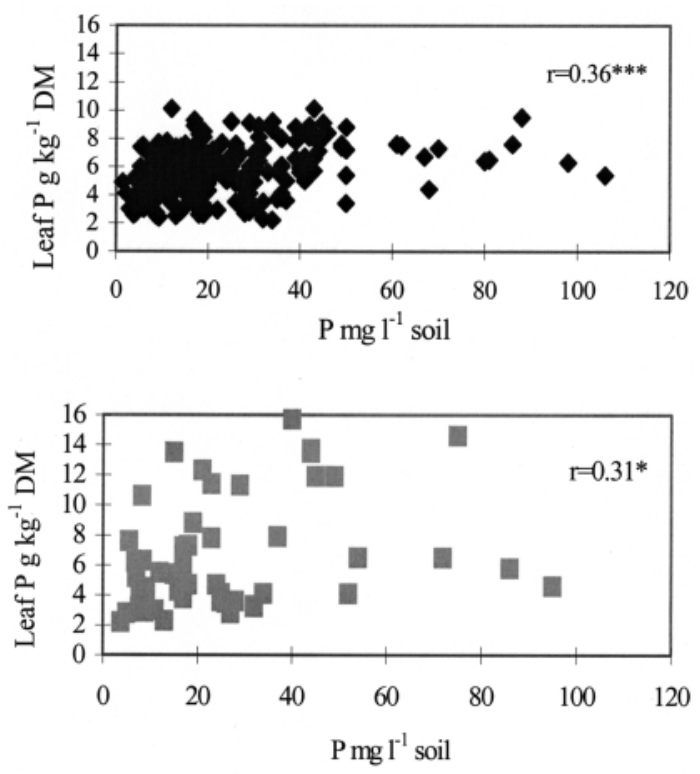

- Black currant $\quad$ Red currant

Fig. 1. Leaf versus soil $P$ in black and red currant fields in 1982-1991 (significance: *** $\mathrm{P}=0.001$, * $\mathrm{P}=0.05$; black currant, $\mathrm{n}=287$, red currant, $\mathrm{n}=51$ ).
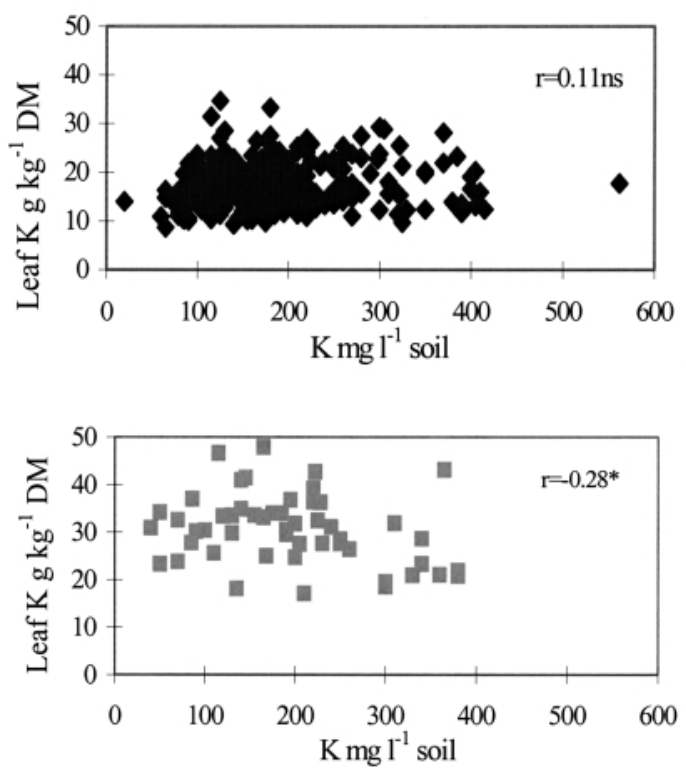

- Black currant

E Red currant

Fig. 3. Leaf versus soil $\mathrm{K}$ in black and red currant fields in 1982-1991 (significance: $* \mathrm{P}=0.05$, $\mathrm{ns}=$ not significant; black currant, $\mathrm{n}=287$, red currant, $\mathrm{n}=51$ ).
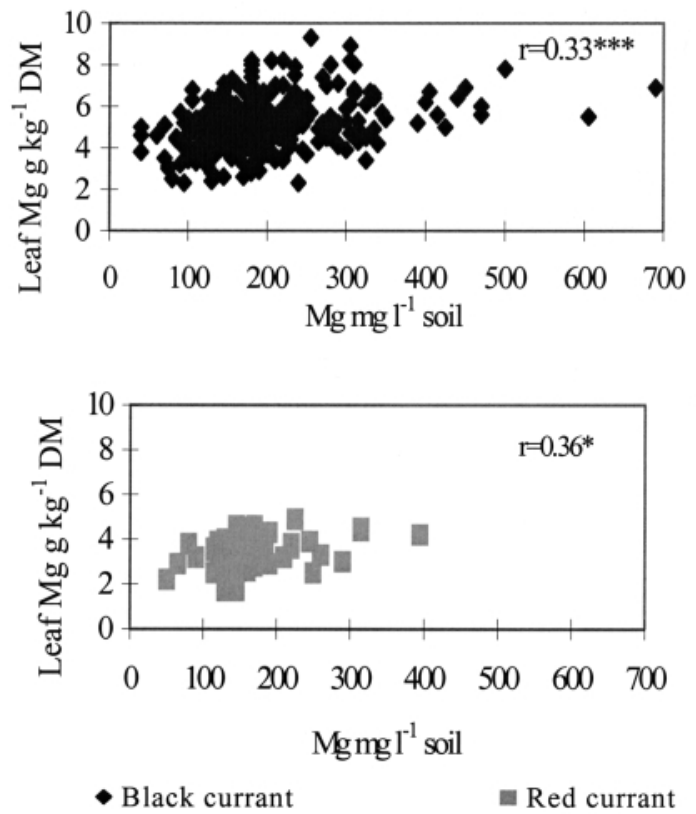

Fig. 2. Leaf versus soil $\mathrm{Mg}$ in black and red currant fields in 1982-1991 (significance: $* * * \mathrm{P}=0.001, * \mathrm{P}=0.05$; black currant, $\mathrm{n}=287$, red currant, $\mathrm{n}=51$ ).

common in soils than in leaves. The fact that soil $\mathrm{P}, \mathrm{Mg}$ and $\mathrm{Ca}$ values commonly fell below the recommended lower limits may reflect the great proportion of coarse soils with rather small nutrient sorption capacity. Furthermore, the $\mathrm{pH}$ was below the recommended lower limit in some of the soil samples. With decreasing $\mathrm{pH}$ the extractability of soil $\mathrm{P}$ by acid ammonium acetate decreases (Hartikainen 1989) and the pH-dependent part of cation exchange capacity diminishes (Mäntylahti and Niskanen 1986). This latter fact is revealed by positive correlation between $\mathrm{pH}$ and extractable $\mathrm{Ca}$ and $\mathrm{Mg}$ representing primarily the exchangeable cation fraction (Niskanen and Jaakkola 1985). In regard to $\mathrm{Mg}$, low values in soil were reflected by low values in the leaves of red and white currants.

Soil and leaf analysis partially gave conflicting impressions of the nutritional status of currant fields. Although the nutritional status was satisfactory according to the soil analysis, the leaf concentrations were low. For example, in 
Vol. 11 (2002): 301-310.

commercial fields $\mathrm{K}$ in black currant leaves tended to decrease in August although the soil K was satisfactory (Niskanen 2001). In this case it was possible that high Ca decreased the uptake of $\mathrm{K}$. Antagonism between the $\mathrm{K}$ and $\mathrm{Ca}$ uptakes of black currant was also found in the study of Ljones (1963). The weak negative correlation between soil and leaf $\mathrm{K}$ in commercial red currant fields might be related to this connection. Rather weak positive correlations were found only in the cases of $\mathrm{P}$ and $\mathrm{Mg}$. In a Norwegian field experiment on black currant, positive correlations between soil and leaf nutrients were found for P, K, Mg and Ca (Ljones 1963). In field experiments on black and red currants carried out by Aaltonen and Dalman (1993), the values of linear correlation coefficients between nutrients in the currant leaves and in the soil were mostly low. Leaf nutrient concentrations were only slightly dependent on soil nutrients also in Finnish commercial apple orchards (Dris et al. 1997, Dris and Niskanen 1998) and strawberry fields (Niskanen and Dris 2002). When the soil nutritional status is at least satisfactory, the poor correlation between nutrient concentrations in soil and in leaf dry matter is obvious and can be due to many factors affecting the availability and uptake of nutrients, e.g. weather conditions, soil moisture and nutrient levels, competition between nutrients in plant uptake, efficiency of shoot growth, amount of yield and incidence of pests. Also the soil and leaf sampling, its timing and how properly it is done, has an effect on how representative the results are. The data from commercial currant fields included material which was analyzed during a period of ten years. Differences in field management and weather conditions during growing seasons could cause variation in the data. Additional variation might be caused by differences in leaf nutrient composition between cultivars. Leaf $\mathrm{Ca}$ has been analyzed only seldom, the data from red and white currant fields was limited and there might be variation in the sampling methods used in different farms. As compared with the results of a single field experiment, different growth conditions and soil characteristics cause more varia- tion in the analysis results of a material collected from many commercial fields. There seemed to be, however, no great differences in the average macronutrient composition of black currant leaves between commercial cultivations and pot and field experiments (Niskanen 2001).

The recommended lower soil analysis limits might be too high for coarse soils, because low values of soil $\mathrm{P}, \mathrm{Mg}$ and $\mathrm{Ca}$ were rather common. It is also possible that nutrient concentrations are not evenly distributed in the sampled soil layer. In order to avoid of breaking the shallow root systems, soil tillage is lacking in perennial crop fields. It has been shown on black currant (Coker 1958) that under nontilled soil the level of root activity is greatest from 5-10 $\mathrm{cm}$ deep, if the surface soil moisture conditions are favorable. In fruit and berry fields the common practice has been to broadcast fertilizers on the soil surface. Therefore, nutrients accumulated in a thin surface soil layer from where the absorption of nutrients by roots has largely taken place. In this case, nutritional status might be satisfactory according to the leaf analysis but according to the soil analysis nutrient levels might be low because in soil sampling higher nutrient concentrations of the thin surface layer have been diluted to a larger sampled soil volume.

High values of soil $\mathrm{B}$ and $\mathrm{Cu}$ were common in currant fields. This can be attributable to the use of compound fertilizers including micronutrients. The repeated surface broadcasting of these fertilizers might have caused enrichment of $\mathrm{B}$ and $\mathrm{Cu}$ in the soil surface layer at a detrimentally high level, because these elements are liable to be tightly bound in soil. High $\mathrm{Cu}$ and $\mathrm{B}$ levels in soil have been commonly found also in strawberry fields (Kukkonen and Uosukainen 1999, Niskanen and Dris 2002). It is considered that low strawberry yields might be partially caused by high soil B concentration. In currant fields it might be also necessary to reconsider the amount of $\mathrm{B}$ and $\mathrm{Cu}$ fertilization.

High soil $\mathrm{P}$ values were found in a part of currant fields. In nontilled soil, broadcasted P is bound to $1-2 \mathrm{~cm}$ thick surface layer and the sol- 


\section{Niskanen, R. Nutritional status in currant fields}

uble $\mathrm{P}$ concentration of this layer increases and may lead to higher loss of $\mathrm{P}$ by surface runoff and drainage water (Turtola and Jaakkola 1995, Turtola and Kemppainen 1998, Turtola and YliHalla 1999). This risk is very possible, because currants are often cultivated on coarse mineral soils and slope fields. The recommended soil $\mathrm{P}$ range for currant fields is rather high as compared the present recommendations for cultivation of cereal and other agricultural crops (YliHalla et al. 2001). It might be necessary to adjust recommendations for soil $\mathrm{P}$ also in currant fields. Furthermore, it could be reasonable to replace surface broadcasting of fertilizers by other fertilization methods like placement fertilization (Niskanen et al. 1999) and fertigation (Kongsrud and Nes 1999) for improvement of the use of nutrients and for prevention of nutrient losses by surface runoff and drainage water.

According to the soil analysis results low $\mathrm{Ca}$, $\mathrm{Mg}, \mathrm{K}$ and $\mathrm{P}$ values were common in currant fields but leaf analysis results were mostly in recommended ranges and did not indicate frequent nutrient deficiences in currant fields. Because the use of commercial analysis of leaf samples has decreased radically, the fertilization has been based only on soil analysis results. Then low soil nutrient values have led to high fertilization recommendations and possibly to use of superfluous high fertilizer doses.

Acknowledgements. The author wishes to thank Soil Testing Service Ltd. for delivering the results of berry series analysis.

\section{References}

Aaltonen, M. 1990. Hämeen tutkimusasemalla: Punaherukan lannoituskokeet jatkuvat - eri menetelmien väliset erot pieniä. Koetoiminta ja Käytäntö 47: 54.

Aaltonen, M. 1992. Miten lannoittaa punaherukkaa? Puutarha 95: 122-123.

Aaltonen, M. \& Dalman, P. 1993. The effect of fertilization on leaf and soil analyses of Ribes rubrum $\mathrm{L}$. and Ribes nigrum L. Acta Horticulturae 352: 21-28.

Aflatuni, A., Prokkola, S. \& Luoma, S. 2001. Mustaherukan lannoitus ja alasleikkaus. Abstract: Fertilization and regeneration cutting of blackcurrant. MTT publications. Series A 99. Jokioinen: MTT Agrifood Research Finland. 44 p. (in Finnish).

Asher, C.J. \& Loneragan, J.F. 1967. Response of plants to phosphate concentration in solution culture: I. Growth and phosphorus content. Soil Science 103: 225-233.

Berger, K.C. \& Truog, E. 1944. Boron tests and determination for soils and plants. Soil Science 57: 25-36.

Bjurman, B. 1971. Studies on the nitrogen and potassium requirements of black currants. Swedish Journal of Agricultural Research 1: 57-67.

Bould, C. 1964. Manurial experiments with fruit. VI: A factorial NPK experiment with black currants, vars. Baldwin and Mendip Cross. The Annual Report of Long Ashton Research Station for 1963. p. 83-89.

Bould, C. 1969. Leaf analysis as a guide to the nutrition of fruit crops. VIII. Sand culture N, P, K, Mg experiments with black currant (Ribes nigrum L.). Journal of the Science of Food and Agriculture 20: 172-181.
Bould, C., Bradfield, E.G. \& Clarke, G.M. 1960. Leaf analysis as a guide to the nutrition of fruit crops. I. General principles, sampling techniques and analytical methods. Journal of the Science of Food and Agriculture 11: 229-242.

Bould, C. \& Parfitt, R.J. 1972. Leaf analysis as a guide to the nutrition of fruit crops. IX. Effects of initial and supplementary levels of $\mathrm{N}$ and $\mathrm{P}$ on black currants (Ribes nigrum L.) grown in sand culture. Journal of the Science of Food and Agriculture 23: 959-968.

Coker, E.G. 1958. The root development of black currants under straw mulch and clean cultivation. Journal of Horticultural Science 33: 21-28.

Dierend, W., Balduf, S. \& Jessen, D. 1998. Nährstoffaufnahme von Roten Johannisbeeren. Erwerbsobstbau 40, 2: 39-42.

Dris, R. \& Niskanen, R. 1998. Nutritional status of commercial apple orchards in the Åland Islands. Acta Agriculturae Scandinavica, Section B, Soil and Plant Science 48: 100-106.

Dris, R., Niskanen, R. \& Voipio, I. 1997. Nutritional Status of Apple Orchards in the Åland Islands 1993-1995. University of Helsinki, Department of Plant Production, Horticulture Section Publication 32. Helsinki. $120 \mathrm{p}$.

Hartikainen, H. 1989. Evaluation of water and ammonium acetate tests as indices for available $P$ in limed soils. Journal of Agricultural Science in Finland 61: 1-6.

Kongsrud, K.L. \& Nes, A. 1999. Effects of fertigation of the black currant cultivar 'Ben Tron' (Ribes nigrum 
Vol. 11 (2002): 301-310.

L.). Acta Horticulturae 505: 409-413.

Kukkonen, S. \& Uosukainen, M. 1999. Perusselvitys mansikan satotason alenemisen syistä ja peltojen tuotantokyvyn palauttaminen 1996-1998. Loppuraportti. Maatalouden tutkimuskeskus. 25 p. + 2 liitettä.

Lakanen, E. \& Erviö, R. 1971. A comparison of eight extractants for the determination of plant available micronutrients in soils. Acta Agralia Fennica 123: 223232.

Larsson, L. \& Svensson, B. 1989. Bärodling. LTs förlag, Stockholm. 216 p.

Ljones, B. 1963. Leaf composition in apple, raspberry and black currant as related to nutrient elements in the soil. Meldinger fra Norges Landbrukshoegskole 42, 5: 1-89.

Ljones, B. 1984. Yield of white currants as related to applied fertilizers, soil analyses and leaf analyses. Meldinger fra Norges Landbrukshoegskole 63, 17: $1-7$.

Mäntylahti, V. \& Niskanen, R. 1986. Effect of acidification on cation exchange capacity of eight Finnish mineral soils. Acta Agriculturae Scandinavica 36: 339-346.

Matala, V. 1999. Herukan viljely. Puutarhaliiton julkaisuja 269. Puutarhaliitto, Helsinki. 266 p.

Niskanen, R. 1989. Herukoiden ravinnetalous. (Nutrition of currants). Helsingin yliopiston puutarhatieteen laitoksen julkaisu 9. Helsinki. 94 p.

Niskanen, R. 2001. Leaf macronutrient composition in relation to growth and yield potential of currants. University of Helsinki, Department of Applied Biology Publication no.2. Helsinki. 123 p.

Niskanen, R. \& Dris, R. 2002. Nutritional status of strawberry fields. Acta Horticulturae 567, 2: 439-442.

Niskanen, R. \& Jaakkola, A. 1985. Comparison of analytical methods in testing soil fertility. Journal of Agricultural Science in Finland 57: 183-194.

Niskanen, R. \& Matala, V. 1991. Jaettu typpilannoitus satoa tuottavilla musta-, puna- ja valkoherukoilla. Kenttäkoe sopimusviljelmillä 1989-1990. (Split application of nitrogen fertilizer on yield producing black, red and white currants. Field experiment on commercial farms in 1989-1990.) Helsingin yliopiston puutarhatieteen laitoksen julkaisu 20. Helsinki. 70 p.

Niskanen, R., Matala, V. \& Voipio, I. 1993. The effect of irrigation on shoot growth in black and red currants. Acta Horticulturae 352: 65-70.

Niskanen, R., Matala, V. \& Voipio, I. 1994. Typpilannoituksen ja sen ajoituksen vaikutus satoa tuottavilla herukkaviljelmillä. Kenttäkoe sopimusviljelmillä 1991-1992. (The effect of nitrogen fertilization and its timing on growth and yield of currants. Field experiment on commercial currant plantations in 19911992). Helsingin yliopiston kasvintuotantotieteen laitos, Puutarhatieteen julkaisuja 24. Helsinki. 81 p.
Niskanen, R., Pesonen, L. \& Hirvenoja, M. 1999. Hedelmän- ja marjanviljelyyn soveltuvan sijoituslannoitusmenetelmän kehittäminen. (Development of placement fertilization method for fruit and berry cultivation). Helsingin yliopiston kasvintuotantotieteen laitos, Puutarhatieteen julkaisuja 35. Helsinki. 85 p. + 11 appendices.

Rupp, D. \& Tränkle, L. 2000. Auswirkungen der Stickstoffdüngung auf Ertrag, Fruchtqualität und vegetative Merkmale bei Roten Johannisbeeren der Sorte 'Rovada'. Erwerbsobstbau 42, 1: 15-20.

Säkö, J. \& Laurinen, E. 1979. The effect of fertilization on black currant in two soils. Annales Agriculturae Fenniae 18: 96-105.

Sillanpää, M. 1982. Micronutrients and the nutrient status of soils: a global study. FAO Soils Bulletin 48. FAO, Rome. 444 p.

Spear, S.N., Asher, C.J. \& Edwards, D.G. 1978. Response of cassava, sunflower, and maize to potassium concentration in solution. Field Crops Research 1: 347361.

Turtola, E. \& Jaakkola, A. 1995. Loss of phosphorus by surface runoff and leaching from a heavy clay soil under barley and grass ley in Finland. Acta Agriculturae Scandinavica B 45: 159-165.

Turtola, E. \& Kemppainen, E. 1998. Nitrogen and phophorus losses in surface runoff and drainage water after application of slurry and mineral fertilizer to perennial grass ley. Agricultural and Food Science in Finland 7: 569-581.

Turtola, E. \& Yli-Halla, M. 1999. Fate of phosphorus applied in slurry and mineral fertilizer: accumulation in soil and release into surface runoff water. Nutrient Cycling in Agroecosystems 55, 2: 165-174.

Vang-Petersen, O. 1973. Bladanalyser I. Tidsskrift for Planteavl 77: 393-398.

Viljavuuspalvelu 1997. Viljavuustutkimuksen tulkinta avomaan puutarhaviljelyssä. Viljavuuspalvelu Oy. $21 \mathrm{p}$.

Voipio, I. \& Niskanen, R. 1990. Musta-, puna- ja valkoherukan kasvu ja sadontuottokyky. (Growth and crop potential of black, red and white currants - a review). Helsingin yliopiston puutarhatieteen laitoksen julkaisuja 15. Helsinki. 617 p.

Vuorinen, J. \& Mäkitie, O. 1955. The method of soil testing in use in Finland. Agrogeological Publications 63: $1-44$.

Yli-Halla, M., Nykänen, A., Siimes, K. \& Tuhkanen, H.-R. 2001. Ympäristötuen ehdot ja maan helppoliukoisen fosforin pitoisuus. Abstract: Agri-Environmental Programme regulations and the easily soluble phosphorus concentration in soil. MTT publications. Series $A$ 77. Jokioinen: MTT Agrifood Research Finland. 45 p. +4 app. (in Finnish). 
Niskanen, $R$. Nutritional status in currant fields

\title{
SELOSTUS
}

\section{Herukkaviljelmien ravinnetila}

\author{
Raina Niskanen \\ Helsingin yliopisto
}

Musta-, puna- ja valkoherukkaviljelmien ravinnetilan määrittämiseksi koottiin Viljavuuspalvelu Oy:n marjasarja-analyysien tuloksia vuosilta 1982-1991. Aineisto käsitti maa-analyysin $\left(\mathrm{pH}, \mathrm{NO}_{3}-\mathrm{N}, \mathrm{P}, \mathrm{K}, \mathrm{Ca}\right.$, $\mathrm{Mg}, \mathrm{B}, \mathrm{Cu}, \mathrm{Mn}$ ) ja herukan lehtien ravinnepitoisuu$\operatorname{det}(\mathrm{N}, \mathrm{P}, \mathrm{K}, \mathrm{Ca}, \mathrm{Mg}, \mathrm{B})$ yhteensä 357 viljelmältä Etelä- ja Keski-Suomesta. Aineistosta selvitettiin, oliko maan ja lehtien ravinnepitoisuuksien välillä yhteyttä, ja kuinka hyvin ravinnepitoisuudet vastasivat suositusarvoja sekä kuvasivat viljelmien ravinnetilaa.

Maanäytteiden keskimääräinen $\mathrm{pH}$ sekä fosforin ja kaliumin pitoisuudet ja $\mathrm{pH}$-korjattu mangaani olivat suositusten mukaisia. Suurimmassa osassa maanäytteistä kalsiumin pitoisuus, yli $60 \%$ näytteistä magnesiumin pitoisuus ja yli $50 \%$ näytteistä fosforin pitoisuus alitti suosituksen, mutta boorin ja kuparin pitoisuudet ylittivät usein suosituksen. Lehtien keskimääräiset typen, fosforin ja kaliumin pitoisuudet kaikilla herukoilla, magnesiumin pitoisuus musta- ja punaherukoilla sekä kalsiumin ja boorin pitoisuudet mustaherukalla olivat suositusten mukaisia. Valkoherukalla $74 \%$ lehtinäytteistä magnesiumpitoisuus alitti suosituksen. Lehtien ja maan fosforin, kalsiumin ja magnesiumin pitoisuuksien välillä oli melko heikko yhteys. Vaikka ravinnetila oli lehtianalyysin perusteella hyvä, maan fosforin, magnesiumin ja kalsiumin pitoisuudet olivat usein pieniä. Tämä viittaa siihen, että karkeilla kivennäismailla maa-analyysin ravinnesuositusten alaraja on liian korkea. Maaanalyysin pienet ravinnepitoisuudet saattavat johtua myös ravinteiden epätasaisesta jakautumisesta ja laimenemisesta maanäytteessä, koska pintalannoituksen ja muokkaamattomuuden vuoksi ravinteet ovat kertyneet aivan maan pintakerrokseen. 